\title{
Review Article \\ Can Mitochondria DNA Provide a Novel Biomarker for Evaluating the Risk and Prognosis of Colorectal Cancer?
}

\author{
Han Shuwen, Yang Xi, and Pan Yuefen \\ Huzhou Central Hospital, No. 198 Hongqi Road, Huzhou, Zhejiang 313000, China \\ Correspondence should be addressed to Pan Yuefen; panyuefen663253@163.com
}

Received 11 January 2017; Accepted 14 February 2017; Published 16 March 2017

Academic Editor: Hong C. Jin

Copyright ( 2017 Han Shuwen et al. This is an open access article distributed under the Creative Commons Attribution License, which permits unrestricted use, distribution, and reproduction in any medium, provided the original work is properly cited.

\begin{abstract}
Colorectal cancer (CRC) was one of the most frequent cancers worldwide. Accurate risk and prognosis evaluation could obtain better quality of life and longer survival time for the patients. Current research hotspot was focus on the gene biomarker to evaluate the risk and prognosis. Mitochondrion contains its own DNA and regulates self-replicating so that it can be as a candidate biomarker for evaluating the risk and prognosis of colorectal cancer. But there were already huge controversies on this issue. The review was to summarize current viewpoints of the controversial issues and described our understanding from the four aspects including mtDNA copy number, mitochondrial displacement loop, mtDNA variation, and mtDNA microsatellite instability, wishing the summary of the mtDNA in colorectal cancer could provide a meaningful reference or a valuable direction in the future studies.
\end{abstract}

\section{Introduction}

Colorectal cancer (CRC) was one of the common types of cancer with a high prevalence of cancer-related morbidity and mortality. Early diagnosis and accurate prognosis evaluation were conducive to reducing the negative health impact. Despite the continuous progress in diagnostic and therapeutic methods, it was still of great significance to seek for the novel biomarkers to evaluate the risk and prognosis of colorectal cancer. The promising biomarkers for this purpose were genes [1], noncoding RNAs [2, 3], proteins [4], gut microorganism [5], and so on. Seeking for more sensitive and accurate biomarker to evaluate the risk and prognosis of colorectal cancer was still striving on the way.

Organelles are the major components of the cells and play an important role in the occurrence and development of cancer cells. The variation of organelles deserves to be the biomarkers to evaluate the risk and prognosis of cancers. Mitochondria, as a vital organelle in almost all eukaryotic cells, have two major functions: oxidative phosphorylation and ATP production [6, 7]. Accumulating evidences suggested the mitochondria played a key role in the cell proliferation [8], cell apoptosis [9], and aging [10]. More, the mtDNA seemed to be involved in a wide range of diseases such as diabetes [11], obesity [12], AIDS [13], and cancers.
Mitochondrion contained its own DNA and regulated self-replicating. MtDNA (mitochondria DNA) was a circular, double-stranded DNA molecule. The outside loop was heavy strand ( $\mathrm{H}$-strand) and the inside was light strand (L-strand). The $\mathrm{H}$-strand and the L-strand contained 28 and 9 genes, respectively. The mtDNA genes were lacking of intron coding regions and the displacement loop (D-loop) was the only one significant noncoding region of the mtDNA. The copies and point mutations of mtDNA varied with different individuals, organs ages, and diseases $[14,15]$. Therefore, mtDNA copy number, mitochondrial displacement loop, and mtDNA variation play an important role in many mitochondrionassociated diseases.

The biological characteristics of mtDNA were as follows: (1) Matrilineal inheritance: matrilineal inheritance was a kind of genetic phenomenon that the genetic information passed down only through the female line. The mtDNA of fathers could not be transferred to the next generation, because the mtDNA of sperm could be specifically recognized and degraded by the ubiquitin hydrolases of ovum. (2) Heterogeneity: the mutations of mtDNA often occurred in the different mitochondria attributing to the mtDNA without the allelic gene like the nDNA (nuclear DNA). The results leaded to both of the mutant type and wild type in the same cells or tissues. (3) Threshold effect: a small number of mutant-type 
mtDNA in the cells could not affect the normal structure or function of the tissues because of the compensation action of wild-type mtDNA. The structure or function of the bodies or tissues could be affected only when the quantity of mutant-type mtDNA exceeded the threshold level [16, 17]. (4) Random distribution: the number and types of mtDNA of the somatic cells or ovum cells were randomly assigned to daughter cells when it passed to next generations [18].

An abundance of studies were concentrated on the association between the mtDNA and the CRC. But there were considerable debates on whether it could be utilized as valuable biomarkers of CRC. The goal of this review was to summarize current viewpoints of the controversial issues and to reveal new directions for future studies.

\section{2. mtDNA Copy Number}

The number of mitochondrial DNAs was different between individuals and between the tissues in human cells [19]. Changes of mitochondrial DNA (mtDNA) copy number were widely reported in CRCs. Both an increase and a decrease in mtDNA copy number had been reported. It remained controversial whether the mtDNA copy number could be utilized as valuable biomarkers to evaluate the risk and prognosis of CRCs. Here we gave a short summary on this subject.

The related literatures and research achievements of mtDNA copy number in CRCs were showed in Table 1. van Osch et al. found that mtDNA copy number was lower in CRC tissues and mtDNA copy number was lower in mutated BRAF and in microsatellite unstable (MSI) tumors, but it was higher in KRAS mutated tumors [20]. Wang et al. reported that the mtDNA copy number was lower in CRC tissues and it was correlated with lymph-node metastasis [21].

However, there were many contradictive views. Wang et al. supported that the mtDNA copy number increased in CRCs and it was a factor of poor prognosis [22]. The researches of Haja Mohideen et al. suggested that mtDNA copy number both increased and decreased in CRCs and no association of the mtDNA copy number change with OS or DFS [23]. More, latest studies in vitro showed both of p53 and TFAM expression could increase mtDNA copy number in CRC lines [24].

In the studies of free circulating mtDNA, Thyagarajan et al. investigated peripheral blood mtDNA copy number in 412 colorectal adenoma cases and 526 cancer-free controls and found there was no association between mitochondrial DNA copy number and colorectal adenomas by the analysis of unconditional logistic regression [25]. Some researchers put forward an idea about the U-shaped association between the relative mtDNA copy number in peripheral blood samples and colorectal cancer risk. Individuals with lower or higher relative mtDNA copy numbers were at increased risk of colorectal cancer [26]. In addition, $\mathrm{Qu}$ et al. found that when the leukocyte mtDNA content was higher, the prognosis in CRC patients was worse [27]. A prospective study found that the leukocytes mtDNA copy number among women who subsequently developed colorectal cancer was lower than that among women who remained cancer-free [28].

\section{D-Loop}

The D-loop (mitochondrial displacement loop) was an mtDNA noncoding region and it was as the major control region for the regulation of mitochondrial genome replication and expression as it contained the leading-strand origin of replication and the main promoter required for transcription. The entire length of D-loop was $1,124 \mathrm{bps}$ according to the mitochondria database http://www.mitomap.org [29-31]. The D-loop was as the research hotspot and its complete or partial sequence had been widely investigated in CRCs. Whether the D-loop could be used to evaluate the risk and prognosis of colorectal cancer, the major point of the controversy was the D-loop mutations site and D-loop mutations frequency.

The related literatures and research results of D-loop in CRCs were showed in Table 2. Feng et al. investigated 44 colorectal cancer tissues and found the ratio of the methylation in D-loop region in colorectal cancer tissues was less than that in the noncancerous tissues [32]. Gao et al. found the similar results in 65 colorectal cancer patients [33]. Govatati et al. investigated the $\mathrm{D}$-loop region of CRC patients in south Indian origin and put forward that $\mathrm{D}$-loop sequence alterations were inherent risk factor for CRCs [34].

Furthermore, Bai et al. believed the minor haplotype of nucleotides $16290 \mathrm{~T}$ in the $\mathrm{D}$-loop region could be used as the biomarker to evaluate the prognosis for postoperative survival of CRCs [35]. And Legras et al. found the mutations of D310 sequence could be considered as a biomarker for early detection of CRCs [36].

Kassem et al. reported that the D-loop mutations frequency was higher in CRC and precancerous colorectal lesions [37], while Akouchekian et al. held that it was more likely to be epiphenomena [38]. But Chang et al. maintained that D-loop mutation occurred at significantly higher frequency in CRCs with p53 mutations [39]. Additionally, Chang et al. held it was not associated with prognosis of CRC patients [39], but Lièvre et al. believed that the D-loop mutation was a factor of poor prognosis in CRCs [40].

\section{4. mtDNA Alterations}

The technique of SNP (Single Nucleotide Polymorphism) was mostly used to investigate the mtDNA alterations in CRCs. The mitochondria DNA, as a biomarker for the diagnosis and prognosis of CRCs, varied from study to study. The controversy was focus on the site and frequency of mtDNA mutation in CRC.

The related literatures and research results of mtDNA alteration in CRCs were showed in Table 3. Numerous research studies showed the mtDNA mutation could be used as a biomarker for the diagnosis and prognosis of CRCs [65, 68, 69]; Chen et al. investigated 104 colorectal cancer patients in China and found the mtDNA proportion of the mtDNA 4977 bp deletion in CRC tissues was decreased [62]. And this view was supported by Dimberg et al. in Swedish and Vietnamese patients [55]. Furthermore, some mtDNA mutations such as mitochondrial subunit ND1 gene [61], G1576A (MTRNR1) and G2975A (MT-RNR2) [70], and mitochondrial 
TABLE 1: Association between the mtDNA copy number and the risk and prognosis in CRC.

\begin{tabular}{|c|c|c|c|c|}
\hline Sample type & Findings & Potential utility & Association & Ref \\
\hline $\begin{array}{l}\text { Cancer, adenoma, and adjacent } \\
\text { normal tissue from CRC patients } \\
(n=56) \text { and recurrent CRC }(n= \\
16) \text {; colon mucosa samples from } \\
\text { healthy subjects }(n=76) .\end{array}$ & $\begin{array}{l}\text { MtDNA copy number in carcinoma } \\
\text { tissues and adjacent tissues was lower } \\
\text { than that in earlier resected adenoma } \\
\text { tissues and MtDNA copy number in } \\
\text { primary CRC tissues was lower than } \\
\text { that in recurrent CRC tissues. }\end{array}$ & $\begin{array}{l}\text { Prognosis } \\
\text { evaluation }\end{array}$ & $\begin{array}{l}\text { The association between mtDNA } \\
\text { and survival seemed to follow an } \\
\text { inverse U-shape with the highest } \\
\text { HR observed in the second } \\
\text { quintile of mtDNA copy number } \\
\text { (HR }=1.70,95 \% \text { CI }=1.18,2.44 \text { ) } \\
\text { compared to the first quintile. }\end{array}$ & [20] \\
\hline $\begin{array}{l}\text { Colorectal cancer tissues }(n=65) \\
\text { and the corresponding } \\
\text { noncancerous tissues. }\end{array}$ & $\begin{array}{c}\text { The mean relative mtDNA copy number } \\
\text { in colorectal cancer tissues was higher } \\
\text { than that in noncancerous tissues. }\end{array}$ & Risk evaluation & Increased in the CRC tissues. & {$[33]$} \\
\hline $\begin{array}{l}\text { Colorectal adenoma tissues }(n= \\
\text { 412) and cancer-free controls }(n= \\
526) \text {. }\end{array}$ & $\begin{array}{c}\text { There was no association between } \\
\text { logarithmically transformed relative } \\
\text { mtDNA copy number and colorectal } \\
\text { adenoma risk. }\end{array}$ & Risk evaluation & No association. & [25] \\
\hline $\begin{array}{l}\text { Colorectal cancer tissues }(n=274) \\
\text { and the corresponding } \\
\text { noncancerous tissues. }\end{array}$ & $\begin{array}{c}\text { The mtDNA copy number was increased } \\
\text { in } 60.4 \% \text { of the CRC tissues. But there } \\
\text { was no association between the mtDNA } \\
\text { copy number and the prognosis. }\end{array}$ & $\begin{array}{l}\text { Risk evaluation } \\
\text { and prognosis } \\
\text { evaluation }\end{array}$ & $\begin{array}{l}\text { Increased in the CRC tissues but } \\
\text { no association with the } \\
\text { prognosis. }\end{array}$ & [23] \\
\hline $\begin{array}{l}\text { Colorectal cancer tissues }(n=9) \\
\text { and cancer-free controls }(n=9) .\end{array}$ & $\begin{array}{l}\text { The mtDNA copy number was } \\
\text { decreased in adenocarcinoma. }\end{array}$ & - & Decreased in adenocarcinoma. & {$[41]$} \\
\hline Leukocyte CRC patients $(n=598)$. & $\begin{array}{l}\text { Patients with high leukocyte mtDNA } \\
\text { content showed worse overall survival } \\
\text { (OS) and relapse-free survival (RFS). }\end{array}$ & $\begin{array}{l}\text { Prognosis } \\
\text { evaluation }\end{array}$ & $\begin{array}{l}\text { Negative correlation between } \\
\text { leukocyte mtDNA content and } \\
\text { prognosis. }\end{array}$ & [27] \\
\hline
\end{tabular}

peripheral leukocytes from CRC Baseline mtDNA copy number was

$(n=444)$ and controls nested $(n=$ lower among women who subsequently Risk evaluation Lower in colorectal cancers. $1,423)$. developed colorectal cancer.

The mtDNA copy number was lower in

Colorectal cancer tissues $(n=60) \quad$ CRC tissues and it was correlated with and the corresponding noncancerous tissues.

lymph-node metastasis. Patients with a lower mtDNA copy number tended to have lower 3-year survival.

\section{Risk evaluation}

and prognosis Decreased in the CRC tissues. evaluation

Colorectal cancer tissues $(n=44)$ The mtDNA copy number was increased and the corresponding in the CRC tissues and this increase was noncancerous tissues. particularly noticeable in stages I and II.

Risk evaluation Increased in the CRC tissues.

422 colorectal cancer cases $(168$ cases with prediagnostic blood and 254 cases with postdiagnostic blood) and 874 controls who were free of colorectal cancer among participants.
There was a U-shaped relationship

between the relative mtDNA copy number and colorectal cancer risk. The lowest and highest quartiles of relative mtDNA copy numbers were 1.81 (1.13-2.89) and 3.40 (2.15-5.36), respectively.
Colorectal cancer tissues $(n=54)$ and the corresponding noncancerous tissues.

Colorectal cancer tissues $(n=25)$ and the corresponding noncancerous tissues.
The mtDNA copy number was increased in the CRC tissues.

The mtDNA copy number was decreased in CRCs.

\author{
U-shaped association between \\ Risk evaluation the relative mtDNA copy number \\ and risk of colorectal cancer.
}

The mitochondrial DNAs copy number was different between individuals and between the tissues in human cells. Changes of mtDNA copy number were widely reported in CRCs. The PCR was used as the most common method to detect the mtDNA copy number in the tissues. There were contradictory points of the association between the mtDNA copy number and the risk and prognosis in CRC.

A12308G in tRNA (Leu(CUN)) [53] were considered as the valuable molecular targets. Besides, some research studies suggested mtDNA mutations heralded poor outcomes and tumorigenesis [44]. But several studies showed no association between mtDNA alterations and CRC risks [52, 64, 71].

\section{5. mtDNA Microsatellite Instability}

It had been already confirmed that MSI-H (high frequency MSI), MSI-L (low frequency MSI), and MSS (microsatellite stability) in human nuclear genome were significantly 
TABLE 2: Association between the D-loop and the risk and prognosis in CRC.

\begin{tabular}{|c|c|c|c|c|}
\hline Sample type & Findings & Potential utility & Targets & Ref \\
\hline $\begin{array}{l}\text { CRC tissues }(n=174) \text { and } \\
\text { cancer-free controls }(n=170)\end{array}$ & $\begin{array}{l}\text { The frequencies of } 310^{\prime} \mathrm{C}^{\prime} \text { insertion }(p= \\
0.0078) \text {, T16189C }(p=0.0097) \text { variants, and } \\
\text { 310'C'ins/16189C haplotype }(p=0.0029) \text { in } \\
\text { colorectal cancer were significantly higher } \\
\text { than that in controls. }\end{array}$ & Risk evaluation & $\begin{array}{l}\text { Nucleotide positions D310 } \\
\text { and D16189 }\end{array}$ & [34] \\
\hline CRC tissues $(n=25)$ & $\begin{array}{l}\text { The D310 mutation was found in } 8 / 25(32 \%) \\
\text { CRCs. }\end{array}$ & Risk evaluation & D310 & [46] \\
\hline
\end{tabular}

The minor haplotype of nucleotides 16290T and frequent haplotype of nucleotide $16298 \mathrm{~T}$ in the hypervariable segment 1 (HV1) region of the D-loop were associated with high

Blood samples from 152 CRC patients the nucleotide site of 16290 was identified as independent predictor for CRCs (RR, 0.379; 95\% CI, $0.171-0.839 ; p=0.017)$.

CRC tissues $(n=65)$ and the corresponding noncancerous tissues
The methylation rate of the $\mathrm{D}$-loop region in colorectal cancer tissues was decreased in clinicopathological stages III and IV comparing with that in stages I and II.

The hypervariable sequence (HV-II) in the loop (D-loop) was significantly associated with the MT-CO2 gene, which represents

\section{Risk evaluation $\quad$ 16290T in HV1 region of and prognosis evaluation}
Prognosis
evaluation

Risk evaluation

and prognosis evaluation the early molecular events in MAP (MUTYH-associated polyposis) tumorigenesis.

HV-II adenocarcinomas and their
corresponding germinal controls

The D-loop of most corresponding noncancerous tissues was methylated and

the percentage was $79.5 \%$, while this percentage was much smaller than that in the tumor tissues (11.4\%). tissues

\begin{tabular}{|c|c|c|c|c|}
\hline Table 4 in the reference & $\begin{array}{l}\text { The rate of D-loop mutations in CRCs was } \\
\text { higher. }\end{array}$ & Risk evaluation & $\begin{array}{l}\text { D-loop mutations } \\
\text { frequency }\end{array}$ & {$[37]$} \\
\hline $\begin{array}{l}\text { Colorectal adenoma tissues }(n= \\
\text { 40) and cancer-free controls }(n= \\
150)\end{array}$ & $\begin{array}{l}\text { The rate of D-loop mutations in CRCs was } \\
\text { higher. }\end{array}$ & Risk evaluation & $\begin{array}{l}\text { D-loop mutations } \\
\text { frequency }\end{array}$ & [38] \\
\hline $\begin{array}{l}\text { CRC tissues with p53 mutation } \\
(n=88) \text { and without p53 } \\
\text { mutation }(n=106)\end{array}$ & $\begin{array}{l}\text { The rate of D-loop mutations was higher in } \\
\text { CRCs with p53 mutation. }\end{array}$ & Risk evaluation & $\begin{array}{l}\text { D-loop mutations } \\
\text { frequency }\end{array}$ & [39] \\
\hline $\begin{array}{l}64 \text { colorectal adenomas (larger } \\
\text { than } 10 \mathrm{~mm} \text { ) and from } 36 \text { liver } \\
\text { metastases of } 15 \text { metastatic CRC } \\
\text { patients. }\end{array}$ & $\begin{array}{l}\text { The mitochondrial D } 310 \text { mutations } \\
\text { frequency increased in the colorectal } \\
\text { adenomas. }\end{array}$ & Risk evaluation & D310 & [36] \\
\hline $\begin{array}{l}\text { Colorectal cancer tissues }(n=25) \\
\text { and the corresponding } \\
\text { noncancerous tissues }\end{array}$ & $\begin{array}{l}40.0 \%(10 / 25) \text { of the colorectal cancers } \\
\text { harbored mutation(s) in the D-loop of } \\
\text { mtDNA. }\end{array}$ & Risk evaluation & $\begin{array}{l}\text { D-loop mutations } \\
\text { frequency }\end{array}$ & {$[41]$} \\
\hline
\end{tabular}

Colorectal cancer tissues $(n=77)$ and the corresponding noncancerous tissues

CRC tissues $(n=35)$ and the corresponding noncancerous tissues

CRC tissues $(n=95)$ and cancer-free controls $(n=95)$
$9 \%(7 / 77)$ of the colorectal cancers harbored mutation(s) in the D-loop region of mtDNA.

\begin{tabular}{|c|c|c|}
\hline $\begin{array}{l}\text { Polymorphisms located in hypervariable } \\
\text { gion I (67.9\%) more than that in II }(32.1 \%) \\
\text { of D-loop. }\end{array}$ & $\begin{array}{l}\text { Risk evaluation } \\
\text { and prognosis } \\
\text { evaluation }\end{array}$ & $\begin{array}{c}\text { Polymorphisms ir } \\
\text { D-loop }\end{array}$ \\
\hline
\end{tabular}

Thirty-two (34\%) CRCs and 2 persons (2\%)

of the cancer-free controls harbored mutations in the D310 region of D-loop.
Risk evaluation D-loop mutations

Risk evaluation

D310

The D-loop (mitochondrial displacement loop) was an mtDNA noncoding region and it was as the major control region for the regulation of mitochondrial genome replication and expression. The rate of D-loop mutations, the site of D-loop mutations, and the methylation rate of D-loop were investigated in CRCs. The table has summarized the current main points. 
TABLE 3: Association between the mtDNA mutation and the risk and prognosis in CRC.

\begin{tabular}{|c|c|c|c|c|}
\hline Sample type & Findings & Potential utility & Targets & Ref \\
\hline $\begin{array}{l}\text { CRC tissues }(n=50) \text { and the } \\
\text { corresponding noncancerous } \\
\text { tissues. Control group comprised } \\
\text { the blood samples from healthy } \\
\text { persons }(n=100) \text {. }\end{array}$ & $\begin{array}{l}\text { There was no association between the } \\
\text { CAG repeat variants in the POLG gene } \\
\text { and colorectal cancer risk. }\end{array}$ & Risk evaluation & $\begin{array}{l}\text { CAG repeat variability in } \\
\text { the POLG gene }\end{array}$ & {$[52]$} \\
\hline $\begin{array}{l}\text { CRC tissues }(n=30) \text {, control } \\
\text { group comprised the blood } \\
\text { samples from healthy persons }(n \\
=100)\end{array}$ & $\begin{array}{l}\text { The A12308G, a polymorphic mutation in } \\
\text { V-loop tRNA (Leu(CUN)), was found in } \\
6 \text { colorectal tumor tissues and } 3 \text { healthy } \\
\text { controls. }\end{array}$ & Risk evaluation & $\begin{array}{l}\text { A12308G alteration in } \\
\text { tRNALeu (CUN) }\end{array}$ & {$[53]$} \\
\hline $\begin{array}{l}60 \text { Vietnamese and } 138 \text { Japanese } \\
\text { CRCs tissues. }\end{array}$ & $\begin{array}{l}\text { The frequency of mtDNA mutations in } \\
\text { the Vietnamese CRCs was higher than } \\
\text { that in the Japanese CRCs }(19 \text { of } 44[43 \%] \\
\text { versus } 11 \text { of } 133[9 \%], p<0.001) .\end{array}$ & Risk evaluation & $\begin{array}{l}\text { mtDNA mutations } \\
\text { frequency }\end{array}$ & [54] \\
\hline
\end{tabular}

CRC tissues from 105 Swedish and 88 Vietnamese patients and the corresponding noncancerous tissues.

CRC tissues $(n=21)$ and the corresponding noncancerous tissues.

CRC tissues $(n=54)$ and the corresponding noncancerous tissues.

Colon cancer $(n=86)$, rectal cancer $(n=43)$, and the corresponding noncancerous tissues.

Three tissues (cancerous, paracancerous, and normal tissues), respectively, from 20 patients.

Hyperplastic polyps $(n=25)$,

The mtDNA 4977 bp deletion was more frequent in normal tissues comparing with paired cancer tissues.

Risk evaluation mtDNA 4977 bp deletion

The mtDNA mutation frequency in the CRC tissues was decreased comparing with adjacent nontumor tissues. mtDNA haplogroup B4 was associated with colorectal cancer risk and poor outcomes.

Risk evaluation mtDNA mutations
frequency

Risk evaluation and prognosis evaluation

mtDNA haplogroup B4

Nonsynonymous mtDNA mutation was
mtDNA mutations frequency found in $57 \%$ of colon and rectal cancer
The frequency of mtDNA mutations: cancerous $>$ paracancerous $>$ normal tissues.
Risk evaluation

Risk evaluation

mtDNA mutations frequency

The mtDNA mutations frequency in carcinomas was not significantly higher

than that in hyperplastic polyps and serrated adenomas.

T4216C mutation was in 8/30 CRC patients.

Risk evaluation mtDNA mutations frequency

Risk evaluation

T4216C mutation serrated adenomas $(n=32)$, traditional serrated adenomas $(n$ $=19)$, and CRCs tissues $(n=138)$.

CRC tissues $(n=30)$ and the corresponding noncancerous tissues.

CRC tissues $(n=30)$ and the corresponding noncancerous tissues. Blood samples were from 25 healthy people.

CRC tissues $(n=104)$ and the corresponding noncancerous tissues.

The mtND1 gene mutations and polymorphisms were in $11(45.8 \%)$ and 13 Risk evaluation Mitochondrial subunit ND1 (mtND1)

[61]

(54.2\%) CRC tissues, respectively.

The 4,977 bp deletion level decreased with the advancing of cancer.

Risk evaluation and prognosis evaluation

4,977 bp deletion in the major arch of the mitochondrial genome

ND1 microsatellite sequence alterations Nuclear microsatellite instability were detected in $2.6 \%$ rectal carcinomas. in 38 rectal carcinomas and 25 ND5 microsatellite sequence alterations sigmoid carcinomas.

were detected in $5.3 \%$ rectal carcinomas

Risk evaluation

ND1 and ND5 and $8 \%$ sigmoid carcinomas.

Five variants showed association with colon cancer. Three variants were associated with risk of CRC for MSI 2854 CRC cases and 2822 controls.
Risk evaluation The T4562C sites [64] T4562C.

The mtDNA mutations frequency and mutations sites were investigated to explore the association between the mtDNA mutation and the risk and prognosis in CRC. But the association between mtDNA mutation and CRCs varied from study to study. 
TABLE 4: Association between the mtDNA microsatellite instability and the risk and prognosis in CRC.

\begin{tabular}{|c|c|c|c|}
\hline Sample type & Findings & Potential utility & Ref \\
\hline $\begin{array}{l}\text { CRC tissues }(n=100) \text { and the } \\
\text { corresponding noncancerous tissues. }\end{array}$ & $\begin{array}{l}\text { The mtMSI was found in } 30 \% \text { of CRCs and it was } \\
\text { associated with the poor prognosis. }\end{array}$ & $\begin{array}{l}\text { Risk evaluation and } \\
\text { prognosis evaluation }\end{array}$ & [65] \\
\hline $\begin{array}{l}83 \text { CRC tissues with a MSI tumor } \\
\text { (including } 39 \text { patients with Lynch } \\
\text { syndrome) and in } 99 \mathrm{mCRC} \text { patients with a } \\
\text { microsatellite stable (MSS) tumor. }\end{array}$ & $\begin{array}{l}\text { The mtMSI was high in mCRC patients with both } \\
\text { MSI and MSS tumors, but no correlation with } \\
\text { prognosis. }\end{array}$ & $\begin{array}{l}\text { Risk evaluation and } \\
\text { prognosis evaluation }\end{array}$ & {$[51]$} \\
\hline $\begin{array}{l}\text { The microdissected cancer epithelia and } \\
\text { adjacent stromas of } 48 \text { sporadic CRCs. }\end{array}$ & $\begin{array}{l}\text { The stromal mtMSI had no association with } \\
\text { stromal nMSI or epithelial mtMSI. }\end{array}$ & Risk evaluation & [66] \\
\hline $\begin{array}{l}\text { CRC tissues }(n=35) \text { and the } \\
\text { corresponding noncancerous tissues. }\end{array}$ & $\begin{array}{c}\text { mtMSI }\left[310^{\prime} \mathrm{C}^{\prime} \text { insertion }(p=0.00001) \text { and }\right. \\
\text { T16189C }(p=0.0007)] \text { was increased in the CRC } \\
\text { tissues. }\end{array}$ & Risk evaluation & [67] \\
\hline
\end{tabular}

Recent studies showed that nuclear genome microsatellite instability was the significant predictor of prognosis CRCs. But the association between the mtDNA microsatellite instability and the risk and prognosis needs to be further confirmed.

associated with the prognosis and recurrence of CRCs [72, 73]. The diagnostic value and prognostic evaluation value of mtMSI (mtDNA microsatellite instability) in CRCs remained undetermined, because the nMSI (nuclear microsatellite instability) had a unique value and significance in CRCs. We believed the mtMSI had a potential value on the risk and prognosis evaluation of colorectal cancer, although the researches in the field were relatively few.

The related literatures and research results of mtMSI in CRCs were showed in Table 4. Some studies suggested there was no association between the stromal mtMSI and stromal nMSI (nuclear microsatellite instability), and the stromal mtMSI was independent of stromal nuclear MSI (microsatellite instability) [66, 74]. A meta-analysis suggested mtMSI was higher in mCRC (metastatic colorectal cancer) patients with both of MSI and MSS in CRCs, but the prognosis was no correlation [51]. Some studies indicated mtMSI was higher in CRCs with Mn-SOD overexpression [67] and the (C)(n) repeat mtMSI was associated with tumor progression [66].

\section{Discussion}

The function of mitochondria was producing the adenosine triphosphate (ATP) via the oxidative phosphorylation system (OXPHOS) in normal physiology. It was generally acknowledged that the numbers of mitochondria showed an increase in high metabolism cells like heart muscle cells. Adequate amounts of energy were a necessary precondition for the uncontrolled rapid proliferation of cancer cells [50]. The number of mitochondria, such logic goes, was increased in the cancer tissues. However, the different researches got different or even contrary conclusions. The uncontrolled rapid proliferation, as the most important feature of cancer cells, was relative in vivo. Many factors including the pharmacological interventions, body's immune system, gene mutation, cancer cell heterogeneity, and nutritional deficiency restricted the proliferation of cancer cells. Thus, the mtDNA copy number as an independent biomarker to evaluate the risk and prognosis of colorectal cancer was inappropriate. But it might be more meaningful to act as the indicator of energy metabolism of cancers. Further studies should be focused on the association between the mtDNA copy number and energy metabolism, angiogenesis, and apoptotic cell proportion in vivo.

The expression of mitochondrial genes was in need of the assistance of the nuclear genes. The mitochondria retrograde cell signaling pathways illustrated that the mtDNA leaded to the changes of nDNA [75]. The number of aberrance mitochondria also affected the stress response and energy metabolism of the cancers. The variations of mutation sites and mutation frequency of mtDNA were found in the CRC tissues. There was a big disparity in the related literatures and research results because the study population had the different nationality, genders, ages, and living environment. We supported that the variations of mutation sites and mutation frequency of mtDNA could be used as auxiliary indicators to evaluate the risk and prognosis of CRC. But independent cohort studies with large sample size should be carried out to reduce the chance of confounding factors affecting investigation results.

The D-loop was the control region to regulate the replication and expression of the mitochondrial genome. More, the expression of the mitochondrial genome was controlled by nuclear DNA. The intertwined relationship between the mtDNA and nuclear DNA was unclear. There were large uncertainties about the association between the variations of mitochondrial genome and the risk and prognosis in CRCs. With the development of bioinformatics and gene sequencing technology, it might provide novel evidences for the mtDNA as the risk and prognosis factor in CRCs by decoding the molecular biological basis of tumorigenesis and progression and complex regulatory networks of interacting molecular components in the future. Besides, there were several interference factors of prognosis of CRCs including the treatment choices, patient's condition, the cancer stages, and biological behavior of cancers in the different researches and investigations. The large range, continuous, and dynamic surveillance of the changes of mtDNA was the further study directions to predict the value and role of the mtDNA.

Recent studies had shown that nuclear genome microsatellite instability was the significant predictor of prognosis CRCs $[50,72]$. Much work remains to be done to make the 
definitive relationship between the mtMSI and nMSI clear. But that did not mean the mtMSI could not act as an interesting predictor to evaluate the prognosis of CRCs. The researches in this field were relatively insufficient. In addition, mtDNA damage and repair system was essential for maintaining genome integrity and stability. Its relevant factors such as Tfam, POLG, and OGG1 may provide clues for the risk and prognosis evaluation of CRCs in the further study.

Moreover, there existed more empirical evidences to support the hypothesis that mtDNA and mitochondrial dysfunction could act as initiator in carcinogenesis. Intensive researches demonstrated that one or several mechanisms such as the mtDNA variation, mitochondrial dynamics [76], excessive quantity increases, mitochondrial enzyme defects [77], and mitochondrial retrograde signaling [78] could bring about global genomes changes that altered cell morphology and function, such as ATP production, calcium homeostasis, integration of metabolism, and regulation of apoptosis, and eventually leaded to tumor formation [79]. The mtDNA and mitochondrial dysfunction plays a vital role in the initiation and progression of malignancies and targeting the mtDNA might be a potential strategy for the development of selective anticancer therapy.

The review was to summarize current viewpoints of the controversial issues and described our understanding from the four aspects including mtDNA copy number, mitochondrial displacement loop, mtDNA variation, and mtDNA microsatellite instability. In conclusion, we believed that the mtDNA could serve as a potential biomarker for evaluating the risk and prognosis of colorectal cancer after conducting more in-depth studies. The summary of the mtDNA provided a meaningful reference and a valuable direction for the future studies.

\section{Conflicts of Interest}

No potential conflicts of interest relevant to this article were reported.

\section{Authors' Contributions}

All authors participated in the conception and design of the study. Han Shuwen and Pan Yuefen conceived the study and drafted the manuscript. Yang Xi made the tables. All authors read and approved the paper.

\section{Acknowledgments}

This work was supported by the Huzhou Public Welfare Technology Application Research Program (2016GYB14).

\section{References}

[1] G. Gibson, "Cancer: directions for the drivers," Nature, vol. 512, no. 1, pp. 31-32, 2014.

[2] K. Lee and L. R. Ferguson, "MicroRNA biomarkers predicting risk, initiation and progression of colorectal cancer," World Journal of Gastroenterology, vol. 22, no. 33, pp. 7389-7401, 2016.
[3] X. Xie, B. Tang, Y.-F. Xiao et al., "Long non-coding RNAs in colorectal cancer," Oncotarget, vol. 7, no. 5, pp. 5226-5239, 2016.

[4] A. Alnabulsi and G. I. Murray, "Integrative analysis of the colorectal cancer proteome: potential clinical impact," Expert Review of Proteomics, vol. 13, no. 10, pp. 917-927, 2016.

[5] M. Yamamoto and S. Matsumoto, "Gut microbiota and colorectal cancer," Genes and Environment, vol. 38, no. 1, article 11, 2016.

[6] E. Silva Ramos, N. G. Larsson, and A. Mourier, "Bioenergetic roles of mitochondrial fusion," Biochimica et Biophysica Acta, vol. 1857, no. 8, pp. 1277-1283, 2016.

[7] F. Hosp, I. Lassowskat, V. Santoro et al., "Lysine acetylation in mitochondria: from inventory to function," Mitochondrion, vol. 33, pp. 58-71, 2017.

[8] S. Shiratsuki, T. Hara, Y. Munakata, K. Shirasuna, T. Kuwayama, and H. Iwata, "Low oxygen level increases proliferation and metabolic changes in bovine granulosa cells," Molecular and Cellular Endocrinology, vol. 437, pp. 75-85, 2016.

[9] X. K. Xing, M. H. Li, Z. W. Guo, and C. S. Xu, "Expression profiles of genes associated with mitochondria-mediated apoptosis and their roles in liver regeneration," Genetics and Molecular Research, vol. 15, no. 3, 2016.

[10] A. Latorre-Pellicer, R. Moreno-Loshuertos, A. V. LechugaVieco et al., "Mitochondrial and nuclear DNA matching shapes metabolism and healthy ageing," Nature, vol. 535, no. 7613, pp. 561-565, 2016.

[11] M. Kubota, Y. B. Shui, M. Liu et al., "Mitochondrial oxygen metabolism in primary human lens epithelial cells: association with age, diabetes and glaucoma," Free Radical Biology and Medicine, vol. 97, pp. 513-519, 2016.

[12] C. Ridler, "Obesity: inheritance via mitochondria," Nature Reviews Endocrinology, vol. 12, no. 9, article 497, 2016.

[13] M. Guzmán-Fulgencio, J. L. Jiménez, M. García-Álvarez et al., "Mitochondrial haplogroups are associated with clinical pattern of AIDS progression in HIV-infected patients," Journal of Acquired Immune Deficiency Syndromes, vol. 63, no. 2, pp. 178183, 2013.

[14] R. M. Andrews, I. Kubacka, P. F. Chinnery, R. N. Lightowlers, D. M. Turnbull, and N. Howell, "Reanalysis and revision of the Cambridge reference sequence for human mitochondrial DNA," Nature Genetics, vol. 23, no. 2, p. 147, 1999.

[15] P. F. Chinnery and G. Hudson, "Mitochondrial genetics," British Medical Bulletin, vol. 106, no. 1, pp. 135-159, 2013.

[16] B. Korzeniewski, M. Malgat, T. Letellier, and J.-P. Mazat, "Effect of 'binary mitochondrial heteroplasmy' on respiration and ATP synthesis: Implications for mitochondrial diseases," Biochemical Journal, vol. 357, no. 3, pp. 835-842, 2001.

[17] R. Rossignol, M. Malgat, J.-P. Mazat, and T. Letellier, “Threshold effect and tissue specificity. Implication for mitochondrial cytopathies," Journal of Biological Chemistry, vol. 274, no. 47, pp. 33426-33432, 1999.

[18] D. C. Wallace, "Mitochondrial diseases in man and mouse," Science, vol. 283, no. 5407, pp. 1482-1488, 1999.

[19] M. Wachsmuth, A. Hübner, M. Li, B. Madea, and M. Stoneking, "Age-related and heteroplasmy-related variation in human mtDNA copy number," PLoS Genetics, vol. 12, no. 3, Article ID e1005939, 2016.

[20] F. H. M. van Osch, A. M. Voets, L. J. Schouten et al., "Mitochondrial DNA copy number in colorectal cancer: between tissue comparisons, clinicopathological characteristics and survival," Carcinogenesis, vol. 36, no. 12, pp. 1502-1510, 2015. 
[21] Y. Wang, V. W. S. Liu, W. C. Xue, A. N. Y. Cheung, and H. Y. S. Ngan, "Association of decreased mitochondrial DNA content with ovarian cancer progression," British Journal of Cancer, vol. 95, no. 8, pp. 1087-1091, 2006.

[22] Y. Wang, S. He, X. Zhu, W. Qiao, and J. Zhang, "High copy number of mitochondrial DNA predicts poor prognosis in patients with advanced stage colon cancer," The International Journal of Biological Markers, vol. 31, no. 4, pp. e382-e388, 2016.

[23] A. M. S. Haja Mohideen, E. Dicks, P. Parfrey, R. Green, and S. Savas, "Mitochondrial DNA polymorphisms, its copy number change and outcome in colorectal cancer," BMC Research Notes, vol. 8, article 272, 2015.

[24] S. Wen, J. Gao, L. Zhang, H. Zhou, D. Fang, and S. Feng, "p53 increase mitochondrial copy number via up-regulation of mitochondrial transcription factor A in colorectal cancer," Oncotarget, vol. 7, no. 46, pp. 75981-75995, 2016.

[25] B. Thyagarajan, W. Guan, V. Fedirko et al., "No association between mitochondrial DNA copy number and colorectal adenomas," Molecular Carcinogenesis, vol. 55, no. 8, pp. 12901296, 2016.

[26] B. Thyagarajan, R. Wang, H. Barcelo, W.-P. Koh, and J.-M. Yuan, "Mitochondrial copy number is associated with colorectal cancer risk," Cancer Epidemiology Biomarkers and Prevention, vol. 21, no. 9, pp. 1574-1581, 2012.

[27] F. Qu, Y. Chen, X. Wang et al., "Leukocyte mitochondrial DNA content: a novel biomarker associated with prognosis and therapeutic outcome in colorectal cancer," Carcinogenesis, vol. 36, no. 5, pp. 543-552, 2015.

[28] B. Huang, Y.-T. Gao, X.-O. Shu et al., "Association of leukocyte mitochondrial DNA copy number with colorectal cancer risk: results from the Shanghai Women's Health Study," Cancer Epidemiology Biomarkers and Prevention, vol. 23, no. 11, pp. 2357-2365, 2014.

[29] H. Sultana, D. W. Seo, M. S. Bhuiyan et al., "Genetic diversity and phylogenetic analysis of South-East Asian duck populations based on the mtDNA D-loop sequences," Asian-Australasian Journal of Animal Sciences, vol. 29, no. 12, pp. 1688-1695, 2016.

[30] J. Zhang, Z. Guo, Y. Bai et al., "Identification of sequence polymorphisms in the displacement loop region of mitochondrial DNA as a risk factor for renal cell carcinoma," Biomedical Reports, vol. 1, pp. 563-566, 2013.

[31] J.-W. Taanman, "The mitochondrial genome: structure, transcription, translation and replication," Biochimica et Biophysica Acta (BBA)-Bioenergetics, vol. 1410, no. 2, pp. 103-123, 1999.

[32] S. Feng, L. Xiong, Z. Ji, W. Cheng, and H. Yang, "Correlation between increased ND2 expression and demethylated displacement loop of mtDNA in colorectal cancer," Molecular Medicine Reports, vol. 6, no. 1, pp. 125-130, 2012.

[33] J. Gao, S. Wen, H. Zhou, and S. Feng, "De-methylation of displacement loop of mitochondrial DNA is associated with increased mitochondrial copy number and nicotinamide adenine dinucleotide subunit 2 expression in colorectal cancer," Molecular Medicine Reports, vol. 12, no. 5, pp. 7033-7038, 2015.

[34] S. Govatati, B. Saradamma, S. Malempati et al., "Association of mitochondrial displacement loop polymorphisms with risk of colorectal cancer in south Indian population," Mitochondrial DNA Part A: DNA Mapping, Sequencing, and Analysis, 2016.

[35] Y. Bai, Z. Guo, J. Xu et al., "Single nucleotide polymorphisms in the D-loop region of mitochondrial DNA is associated with renal cell carcinoma outcome," Mitochondrial DNA, vol. 26, no. 2, pp. 224-226, 2015.
[36] A. Legras, A. Lièvre, C. Bonaiti-Pellié et al., "Mitochondrial D310 mutations in colorectal adenomas: an early but not causative genetic event during colorectal carcinogenesis," International Journal of Cancer, vol. 122, no. 10, pp. 2242-2248, 2008.

[37] A. M. Kassem, N. El-Guendy, M. Tantawy, H. Abdelhady, A. El-Ghor, and A. H. Abdel Wahab, "Mutational hotspots in the mitochondrial D-loop region of cancerous and precancerous colorectal lesions in egyptian patients," DNA and Cell Biology, vol. 30, no. 11, pp. 899-906, 2011.

[38] M. Akouchekian, M. Houshmand, S. Hemati, M. Ansaripour, and M. Shafa, "High rate of mutation in mitochondrial DNA displacement loop region in human colorectal cancer," Diseases of the Colon and Rectum, vol. 52, no. 3, pp. 526-530, 2009.

[39] S. C. Chang, P. C. Lin, S. H. Yang, H. S. Wang, W. Y. Liang, and J. K. Lin, "Mitochondrial D-loop mutation is a common event in colorectal cancers with p53 mutations," International Journal of Colorectal Disease, vol. 24, no. 6, pp. 623-628, 2009.

[40] A. Lièvre, C. Chapusot, A.-M. Bouvier et al., "Clinical value of mitochondrial mutations in colorectal cancer," Journal of Clinical Oncology, vol. 23, no. 15, pp. 3517-3525, 2005.

[41] L. F. de Araujo, A. S. Fonseca, B. R. Muys et al., "Mitochondrial genome instability in colorectal adenoma and adenocarcinoma," Tumor Biology, vol. 36, no. 11, pp. 8869-8879, 2015.

[42] H. Cui, P. Huang, Z. Wang et al., "Association of decreased mitochondrial DNA content with the progression of colorectal cancer," BMC Cancer, vol. 13, article 110, 2013.

[43] S. Feng, L. Xiong, Z. Ji, W. Cheng, and H. Yang, "Correlation between increased copy number of mitochondrial DNA and clinicopathological stage in colorectal cancer," Oncology Letters, vol. 2, no. 5, pp. 899-903, 2011.

[44] S. W. Lim, H. R. Kim, H. Y. Kim et al., "High-frequency minisatellite instability of the mitochondrial genome in colorectal cancer tissue associated with clinicopathological values," International Journal of Cancer, vol. 131, no. 6, pp. 1332-1341, 2012.

[45] H.-C. Lee, P.-H. Yin, J.-C. Lin et al., "Mitochondrial genome instability and mtDNA depletion in human cancers," Annals of the New York Academy of Sciences, vol. 1042, pp. 109-122, 2005.

[46] W. R. R. Geurts-Giele, G. H. G. K. Gathier, P. N. Atmodimedjo, H. J. Dubbink, and W. N. M. Dinjens, "Mitochondrial D310 mutation as clonal marker for solid tumors," Virchows Archiv, vol. 467, no. 5, pp. 595-602, 2015.

[47] C. Wang, S. Zhao, Y. Du, and Z. Guo, "Single nucleotide polymorphisms in the D-loop region of mitochondrial DNA is associated with colorectal cancer outcome," Mitochondrial DNA Part A: DNA Mapping, Sequencing, and Analysis, vol. 27, no. 6, pp. 4361-4363, 2016.

[48] E. Errichiello, A. Balsamo, M. Cerni, and T. Venesio, "Mitochondrial variants in MT-CO2 and D-loop instability are involved in MUTYH-associated polyposis," Journal of Molecular Medicine, vol. 93, no. 11, pp. 1271-1281, 2015.

[49] K. Hibi, H. Nakayama, T. Yamazaki et al., "Detection of mitochondrial DNA alterations in primary tumors and corresponding serum of colorectal cancer patients," International Journal of Cancer, vol. 94, no. 3, pp. 429-431, 2001.

[50] Z. Gatalica, S. Vranic, J. Xiu, J. Swensen, and S. Reddy, "High microsatellite instability (MSI-H) colorectal carcinoma: a brief review of predictive biomarkers in the era of personalized medicine," Familial Cancer, vol. 15, no. 3, pp. 405-412, 2016.

[51] S. Venderbosch, S. van Vliet, M. H. C. Craenmehr et al., "Mitochondrial microsatellite instability in patients with metastatic colorectal cancer," Virchows Archiv, vol. 466, no. 5, pp. 495-502, 2015. 
[52] K. Linkowska, A. Jawien, A. Marszałek, K. Skonieczna, and T. Grzybowski, "Searching for association of the CAG repeat polymorphism in the mitochondrial DNA polymerase gamma gene (POLG) with colorectal cancer," Acta Biochimica Polonica, vol. 62, no. 3, pp. 625-627, 2015.

[53] F. Mohammed, A. R. Rezaee khorasany, E. Mosaieby, and M. Houshmand, "Mitochondrial A12308G alteration in tRNA(Leu(CUN)) in colorectal cancer samples," Diagnostic Pathology, vol. 10, no. 1, article 115, 2015.

[54] T. Miwata, T. Hiyama, D. T. R. Quach et al., "Differences in Kras and mitochondrial DNA mutations and microsatellite instability between colorectal cancers of Vietnamese and Japanese patients," BMC Gastroenterology, vol. 14, article 203, 2014.

[55] J. Dimberg, T. T. Hong, M. Skarstedt, S. Löfgren, N. Zar, and A. Matussek, "Novel and differential accumulation of mitochondrial DNA deletions in Swedish and Vietnamese patients with colorectal cancer," Anticancer Research, vol. 34, no. 1, pp. 147152, 2014.

[56] N. G. Ericson, M. Kulawiec, M. Vermulst et al., "Decreased mitochondrial DNA mutagenesis in human colorectal cancer," PLoS Genetics, vol. 8, no. 6, Article ID e1002689, 2012.

[57] T. C. Larman, S. R. DePalma, A. G. Hadjipanayis et al., "Spectrum of somatic mitochondrial mutations in five cancers," Proceedings of the National Academy of Sciences of the United States of America, vol. 109, no. 35, pp. 14087-14091, 2012.

[58] C.-Y. Wang, H. Li, X.-D. Hao et al., "Uncovering the profile of somatic mtDNA mutations in Chinese Colorectal cancer patients," PLoS ONE, vol. 6, no. 6, Article ID e21613, 2011.

[59] T. Shimomura, T. Hiyama, S. Oka et al., "Frequent somatic mutations of mitochondrial DNA in traditional serrated adenomas but not in sessile serrated adenomas of the colorectum," Journal of Gastroenterology and Hepatology, vol. 26, no. 10, pp. 1565-1569, 2011.

[60] M. Akouchekian, M. Houshmand, M. H. H. Akbari, B. Kamalidehghand, and M. Dehghane, "Analysis of mitochondrial ND1 gene in human colorectal cancer," Journal of Research in Medical Sciences, vol. 16, no. 1, pp. 50-55, 2011.

[61] Y. Yusnita, M. D. Norsiah, and A. J. A Rahman, "Mutations in mitochondrial NADH dehydrogenase subunit 1 (mtND1) gene in colorectal carcinoma," Malaysian Journal of Pathology, vol. 32, no. 2, pp. 103-110, 2010.

[62] T. Chen, J. He, L. Shen et al., "The mitochondrial DNA 4,977bp deletion and its implication in copy number alteration in colorectal cancer," BMC Medical Genetics, vol. 12, article 8, 2011.

[63] M. Pinheiro, I. Veiga, C. Pinto et al., "Mitochondrial genome alterations in rectal and sigmoid carcinomas," Cancer Letters, vol. 280, no. 1, pp. 38-43, 2009.

[64] E. Webb, P. Broderick, I. Chandler et al., "Comprehensive analysis of common mitochondrial DNA variants and colorectal cancer risk," British Journal of Cancer, vol. 99, no. 12, pp. 20882093, 2008.

[65] J.-H. Lee, I. Hwang, Y.-N. Kang, I.-J. Choi, and D.-K. Kim, "Genetic characteristics of mitochondrial DNA was associated with colorectal carcinogenesis and its prognosis," PLOS ONE, vol. 10, no. 3, Article ID e0118612, 2015.

[66] H. S. Kim, H. S. Lim, S. H. Lee et al., "Mitochondrial microsatellite instability of colorectal cancer stroma," International Journal of Cancer, vol. 119, no. 11, pp. 2607-2611, 2006.

[67] S. Govatati, S. Malempati, B. Saradamma et al., "Manganesesuperoxide dismutase (Mn-SOD) overexpression is a common event in colorectal cancers with mitochondrial microsatellite instability," Tumor Biology, vol. 37, no. 8, pp. 10357-10364, 2016.
[68] H. Takeuchi, A. Fujimoto, and D. S. B. Hoon, "Detection of mitochondrial DNA alterations in plasma of malignant melanoma patients," Annals of the New York Academy of Sciences, vol. 1022, pp. 50-54, 2004.

[69] G. Adams Jr., S. Mehrabi, Y. Vatcharapijarn et al., "Frequencies of mtDNA mutations in primary tissues of colorectal adenopolyps," Frontiers in Bioscience (Elite Edition), vol. 5, no. 3, pp. 809-813, 2013.

[70] N. Chihara, T. Amo, A. Tokunaga et al., "Mitochondrial DNA alterations in colorectal cancer cell lines," Journal of Nippon Medical School, vol. 78, no. 1, pp. 13-21, 2011.

[71] H. Ashktorab, S. Ahuja, L. Kannan et al., "A meta-analysis of MSI frequency and race in colorectal cancer," Oncotarget, vol. 7, no. 23, pp. 34546-34557, 2016.

[72] M. Srdjan, A. Jadranka, D. Ivan et al., "Microsatellite instability \& survival in patients with stage II/III colorectal carcinoma," The Indian Journal of Medical Research, vol. 143, pp. S104-S111, 2016.

[73] E. N. Mojarad, S. M. H. Kashfi, H. Mirtalebi et al., "Low level of microsatellite instability correlates with poor clinical prognosis in stage II colorectal cancer patients," Journal of Oncology, vol. 2016, Article ID 2196703, 9 pages, 2016.

[74] G. Guleng, T. Løvig, G. I. Meling, S. N. Andersen, and T. O. Rognum, "Mitochondrial microsatellite instability in colorectal carcinomas-frequency and association with nuclear microsatellite instability," Cancer Letters, vol. 219, no. 1, pp. 97-103, 2005.

[75] F. M. da Cunha, N. Q. Torelli, and A. J. Kowaltowski, "Mitochondrial retrograde signaling: triggers, pathways, and outcomes," Oxidative Medicine and Cellular Longevity, vol. 2015, Article ID 482582, 10 pages, 2015.

[76] S. Srinivasan, M. Guha, A. Kashina, and N. G. Avadhani, "Mitochondrial dysfunction and mitochondrial dynamics-the cancer connection," Biochimica et Biophysica Acta (BBA)-Bioenergetics, 2017.

[77] M. Miyo, M. Konno, H. Colvin et al., "The importance of mitochondrial folate enzymes in human colorectal cancer," Oncology Reports, vol. 37, no. 1, pp. 417-425, 2017.

[78] L. Formentini, M. Sánchez-Aragó, L. Sánchez-Cenizo, and J. M. C. Cuezva, "The mitochondrial ATPase inhibitory factor 1 triggers a ROS-mediated retrograde prosurvival and proliferative response," Molecular Cell, vol. 45, no. 6, pp. 731-742, 2012.

[79] C. C. Hsu, L. M. Tseng, and H. C. Lee, "Role of mitochondrial dysfunction in cancer progression," Experimental Biology and Medicine, vol. 241, no. 12, pp. 1281-1295, 2016. 


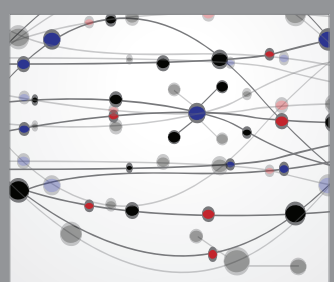

The Scientific World Journal
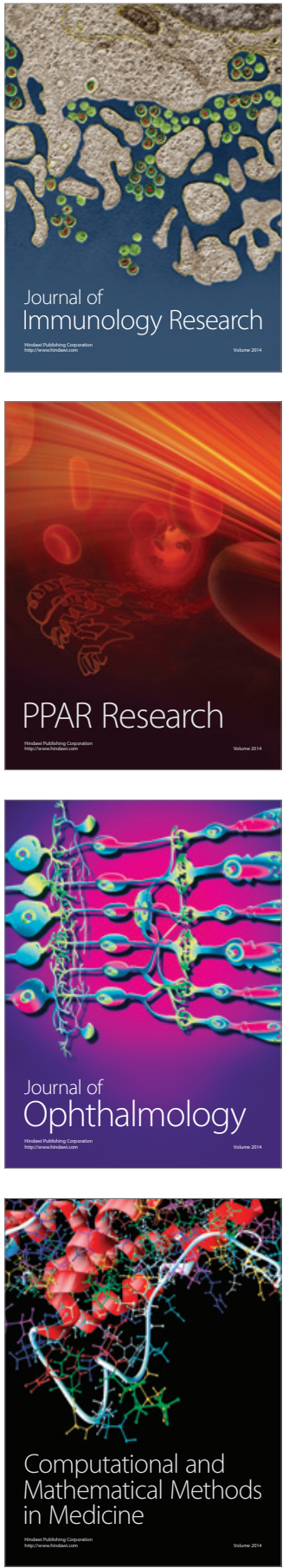

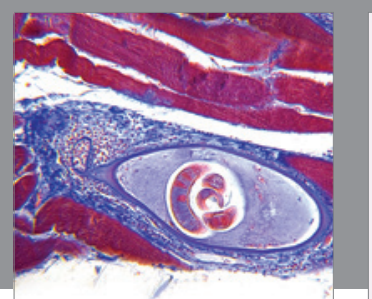

Gastroenterology Research and Practice
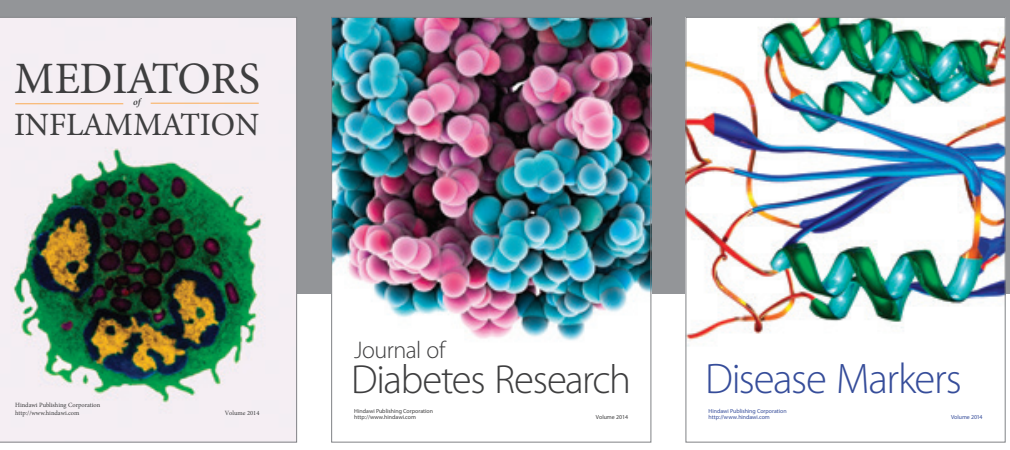

Disease Markers

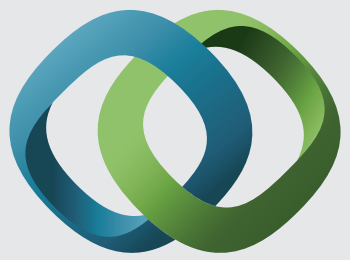

\section{Hindawi}

Submit your manuscripts at

https://www.hindawi.com
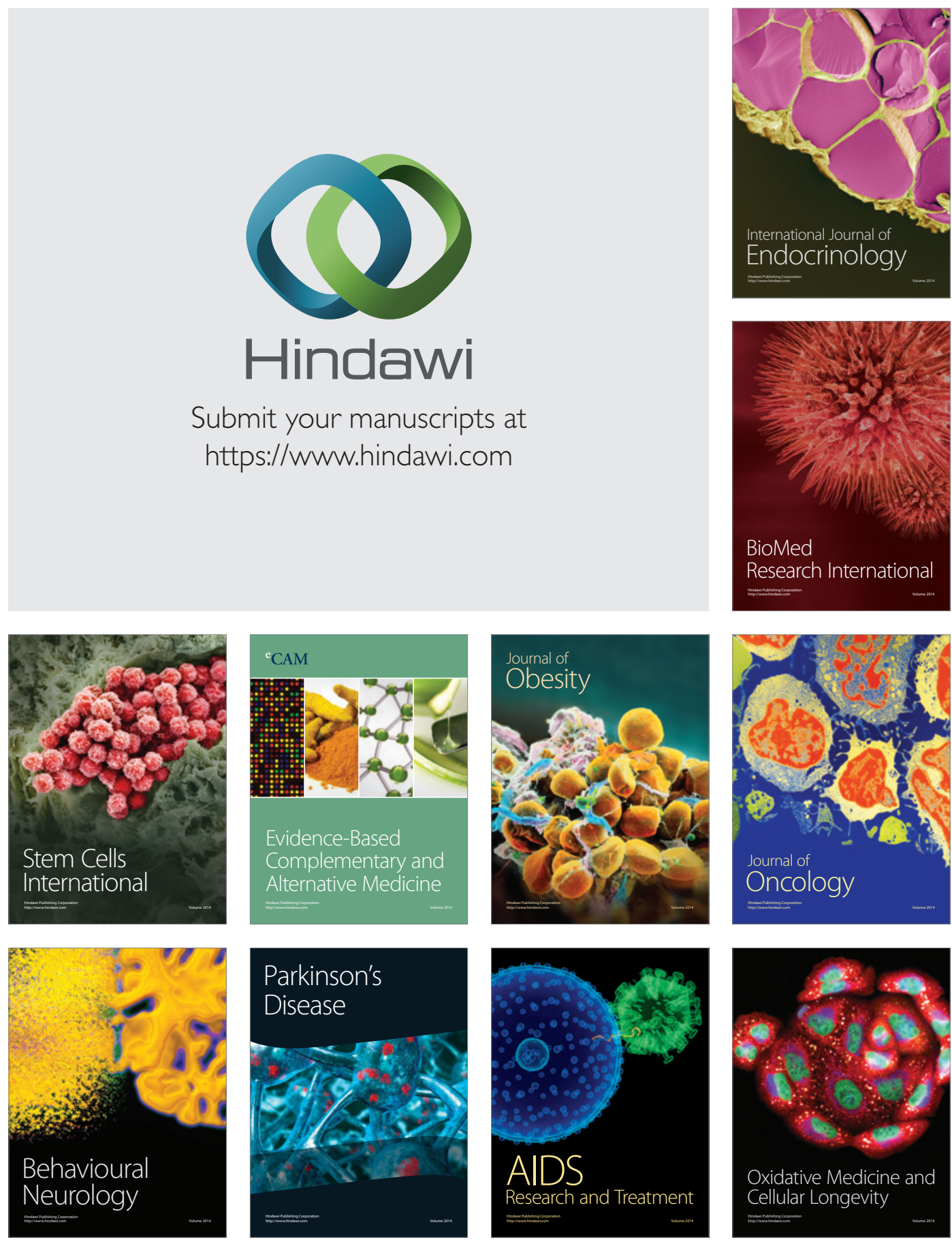